\title{
SUBSTRATES, EMERGENCE AND SEEDLING QUALITY OF Hymenaea stigonocarpa MART. (JATOBA) IN PROTECTED CULTIVATION
}

\author{
SUBSTRATOS, EMERGÊNCIA E QUALIDADE DE MUDAS DE Hymenaea \\ stigonocarpa MART (JATOBÁ) EM CULTIVO PROTEGIDO
}

\author{
Léia Carla dos Santos Rodrigues LARSON; Aparecida Conceição BOLIANI²; \\ Tiago Lima do Espírito SANTO'; ${ }^{1}$ Paulo Eduardo TEODORO ${ }^{3}$; Edilson COSTA ${ }^{4}$ \\ 1. Universidade Estadual do Mato Grosso do Sul - UEMS, Unidade Universitária de Aquidauana, Brasil; 2. Universidade Estadual \\ Paulista "Julio de Mesquita Filho" - UNESP, Campus de Ilha Solteira, Brasil ; 3. Universidade Federal do Mato Grosso do Sul - UFMS, \\ Campus de Chapadão do Sul, Brasil; 4. UEMS, Unidade Universitária de Cassilândia, Brasil. edutedoro@ hotmail.com
}

\begin{abstract}
Because the consumption and use of native fruit, there is need for research on strategies for maintenance propagation of the species. Jatoba is a fruitful tree of great importance to the Brazilian fauna, cuisine and reclamation and thus is essential to obtain high quality seedlings. This study aimed at the formation of Jatoba seedlings on different substrates. The experiment was conducted at Experimental Farm for Teaching, Research and Extension of UNESP, Campus Ilha Solteira, SP, located in Selvíria/MS for the period 13 October 2011 to 11 February. For producing the seedlingsm we used a black screen of polypropylene $\left(\right.$ Sombrite ${ }^{\circledR}$ ) with $50 \%$ light reduction and black plastic bags $15 \mathrm{x}$ $21,5 \mathrm{~cm}(1.8 \mathrm{~L})$ filed with different substrates: (S1) soil control; $(\mathrm{S} 2)$ soil $(50 \%)+$ manure $(50 \%)$; (S3) soil + mineral fertilizer; (S4) soil $(50 \%)+$ mineral fertilizer + manure $(50 \%)$; (S5) soil + limestone; (S6) soil $(50 \%)+$ limestone + manure (50\%); (S7) soil + mineral fertilizer + limestone; (S8) soil $(50 \%)+$ limestone + manure + mineral fertilizer $(50 \%)$. Emergence of seeds was evaluated daily and fortnightly and after emergence of seeds were observed height and stem diameter. At 120 days after emergence, we evaluated the length of root system, shoot and root dry mass, total dry mass, shoot/ lap diameter (S/D), relation between shoot and root dry mass (SDM/RDM), relation between shoot and root fresh mass (SFM/RFM), relation between length of shoot/root (LS/LR) and Dickson's Quality Score (DQS). Experimental design was completely randomized in factorial with $8 \times 7$ reviews substrates. Proceeded with analysis of variance unfolding of significant interactions with the Tukey test for comparisons of means of the substrate factor and time factor for polynomial regression. Treatment pure soil substrate (S1) provided to the Jatoba seedlings the largest biomass formation of shoot and root dry mass. The addition of manure to the substrate did not benefit the development of the Jatoba seedlings.
\end{abstract}

KEYWORDS: Mineral fertilizer. Soil. Manure. Jatobazeiro. Propagation.

\section{INTRODUCTION}

A lot of native fruits have commercial potential to generate income, however, they are often not approved given the lack of information on their agricultural management and the fact that their exploited forms of extractivism are disorganised. Silva et al. (2001) emphasized that many native species may serve as different alternatives for orchards; for environmental protection; and for the recovery of deforested or degraded areas. Among these species, Jatoba, for instance, can be usedas a food source; raw material for medicinal products; for handicrafts (FARIA et al., 2006), among many others. Due to its high size and species characteristics, it can also be an alternative for silvopasture systems (NICODEMOS et al., 2007), with profits in two activities, grazing and timber extraction, besides helping the local environmental preservation.

Therefore, researches on propagation methods; dormancy breakage; and on the most suitable substrate type for seedling development and its establishment in commercial crops are needed. According to Santos et al. (2011), Jatoba is adaptable to few fertile soils (Cerrado) even though it does not require high nutrition substrate for its initial development, just as Duboc et al. (2006) reported that Hymenaea courbaril presents a small nutritional requirement in the formation of seedlings for $\mathrm{N}, \mathrm{P}, \mathrm{Ca}, \mathrm{Mg}, \mathrm{S}$ and $\mathrm{K}$, and that the excess of $\mathrm{B}$ and $\mathrm{Zn}$ can be phytotoxic.

One of the main difficulties in the formation of commercial orchards of many native fruit trees is the lack of certified seedlings, information on seed management and seasonality of the species. Scremin-Dias et al. (2006) discuss that the greater the number of information on the management of fruit plants, their productive techniques will be facilitated. This information creates database for nurseries, facilitating the production of sufficient seedlings to the productive demand. Lorenzi (2000) It explains that the jatobazeiro seedling production time is relatively fast, as in the development at field 
is slow, however, Sano and Fonseca (2003) reported large viability of planting Jatoba seedlings in the field, due to its high survival. Thus, the objective of this work was to evaluate substrates in the emergence and seedling quality of Hymenaea stignocarpa Mart. (Jatoba).

\section{MATERIAL AND METHODS}

The trial was conducted in the period from October 13, 2011 to February 11, 2012 at experimental area of Teaching, Research and Extension Farm of the Unesp, Campus Ilha Solteira - SP, located in the municipality of Selvíria - MS, with latitude $20^{\circ} 25^{\prime} \mathrm{S}$ and longitude $51^{\circ} 21^{\prime} \mathrm{W}$. Region climate according to Köppen classification is Aw (warm tropical with rains in summer), with an average annual temperature of $24.5^{\circ} \mathrm{C}$ and average annual rainfall of $1.232 \mathrm{~mm}$ (HERNANDEZ et al., 1995).

For the production of seedlings was used nursery with polypropylene mesh with $50 \%$ light reduction and plastic bags of $15 \times 21.5 \mathrm{~cm}$ with capacity of $1.8 \mathrm{~L}$, which were filled with different combinations of soil-base substrates - S1: soil (control); S2: soil $(50 \%)+$ cattle manure $(50 \%)$; S3: soil + mineral fertilizer; S4: soil $(50 \%)+$ mineral fertilizer + cattle manure $(50 \%)$; S5: soil + limestone; S6: soil $(50 \%)+$ limestone + cattle manure $(50 \%)$; S7: soil + limestone + mineral fertilizer; S8: soil $(50 \%)+$ limestone + mineral fertilizer + cattle manure $(50 \%)$.

Soil used was removed from the abovementioned experimental area from $0-20 \mathrm{~cm}$ layer and subjected to chemical analysis in the Instituto Agrônomico de Campinas, SP (IAC) (Table 1), being classified as Red Latossolo Distrophic typical clayey to moderate, hypodistrophic, alic, kaolinitic, ferric, very deep, moderately acid (EMBRAPA, 1999).

In some substrates limestone was carried out to raise the base saturation to $50 \%$. In the mineral fertilization, we applied $3 \mathrm{~kg}$ of $\mathrm{P}_{2} \mathrm{O}_{5}$ (648 g simple superphosphate) and 500g of $\mathrm{K}_{2} \mathrm{O}$ (108 g potassium chloride), applied on a volume basis of $1 \mathrm{~m}^{3}$ of substrate (SÃO JOSÉ, 1992). Cattle manure was tanned for 5 months, being revolved and irrigated weekly. The chemical analysis of manure and limestone was carried out to better understand the results obtained in the Laboratory of Fertilizers and Residues (IAC) (Table 2) according to the procedure described in MAPA (2007).

Table 1. Chemical analysis of the substrates for production of seedlings of Hymenaea stigonocarpa Mart. Selvíria - MS, $2011-2012$.

\begin{tabular}{|c|c|c|c|c|c|c|c|c|c|}
\hline \multirow[b]{2}{*}{ Parameters } & \multirow[b]{2}{*}{ Units } & \multicolumn{8}{|c|}{ Substrates } \\
\hline & & S1 & S2 & S3 & S4 & S5 & S6 & S7 & S8 \\
\hline $\mathrm{OM}$ & $\left(\mathrm{g} / \mathrm{dm}^{3}\right)$ & 14 & 55 & 16 & 59 & 15 & 50 & 16 & 51 \\
\hline $\mathrm{pH}$ & - & 4.4 & 4.9 & 4.8 & 5 & 5.2 & 5.1 & 5.2 & 5.3 \\
\hline E.C & $(\mathrm{dS} / \mathrm{m})$ & 0.1 & 0.9 & 0.1 & 1.3 & 0.3 & 5.2 & 1.1 & 1.6 \\
\hline $\mathrm{Ca}$ & $\left(\mathrm{mmolc} / \mathrm{dm}^{3}\right)$ & 5 & 94 & 9 & 12 & 27 & 18 & 38 & 23 \\
\hline $\mathrm{P}$ & $\left(\mathrm{mg} / \mathrm{dm}^{3}\right)$ & 4 & 488 & 39 & 696 & 11 & 416 & 63 & 448 \\
\hline K & $\left(\mathrm{mmolc} / \mathrm{dm}^{3}\right)$ & 0.8 & 2.6 & 2.9 & 2.5 & 1.7 & 3.1 & 5 & 2.9 \\
\hline $\mathrm{Mg}$ & $\left(\mathrm{mmolc} / \mathrm{dm}^{3}\right)$ & 2 & 35 & 4 & 38 & 15 & 55 & 13 & 45 \\
\hline S & $\left(\mathrm{mg} / \mathrm{dm}^{3}\right)$ & 6 & 20 & 9 & 26 & 5 & 80 & 202 & 70 \\
\hline S.B. & $\left(\mathrm{mmolc} / \mathrm{dm}^{3}\right)$ & 8.2 & 135.9 & 16.2 & 58.7 & 43.9 & 86.1 & 58 & 79.7 \\
\hline $\mathrm{H}+\mathrm{Al}$ & $\left(\mathrm{mmolc} / \mathrm{dm}^{3}\right)$ & 28 & 20 & 28 & 18 & 16 & 13 & 20 & 15 \\
\hline CEC & $\left(\mathrm{mmolc} / \mathrm{dm}^{3}\right)$ & 36.2 & 155.9 & 44.2 & 76.7 & 59.9 & 99.1 & 78 & 94.7 \\
\hline V & $(\%)$ & 23 & 87 & 37 & 77 & 73 & 87 & 74 & 84 \\
\hline $\mathrm{Al}$ & $\left(\mathrm{mmolc} / \mathrm{dm}^{3}\right)$ & 4 & -1 & 2 & -1 & 0 & -1 & 0 & -1 \\
\hline $\mathrm{Na}$ & $\left(\mathrm{mmolc} / \mathrm{dm}^{3}\right)$ & 0.4 & 4.3 & 0.3 & 6.2 & 0.2 & 10 & 2 & 8.8 \\
\hline $\mathrm{Cu}$ & $\left(\mathrm{mg} / \mathrm{dm}^{3}\right)$ & 0.6 & 1.4 & 0.9 & 1.7 & 0.7 & 0.9 & 0.6 & 1.2 \\
\hline $\mathrm{Fe}$ & $\left(\mathrm{mg} / \mathrm{dm}^{3}\right)$ & 10 & 27 & 16 & 29 & 10 & 14 & 12 & 18 \\
\hline $\mathrm{Mn}$ & $\left(\mathrm{mg} / \mathrm{dm}^{3}\right)$ & 11.5 & 19.1 & 15.3 & 22.8 & 4.2 & 2.3 & 6.2 & 16.1 \\
\hline $\mathrm{Zn}$ & $\left(\mathrm{mg} / \mathrm{dm}^{3}\right)$ & 0.5 & 13.6 & 1.6 & 19.9 & 1 & 11.6 & 0.6 & 9.7 \\
\hline B & $\left(\mathrm{mg} / \mathrm{dm}^{3}\right)$ & 0.17 & 0.35 & 0.2 & 0.39 & 0.19 & 0.33 & 0.2 & 0.34 \\
\hline
\end{tabular}

Substrates: S1: soil; S2: soil + cattle manure $(50 \%+50 \%)$; S3: soil + mineral fertilizer; S4: soil + mineral fertilizer + cattle manure; S5: soil + limestone; S6: soil + limestone + cattle manure; S7: soil + limestone + mineral fertilizer; S8: soil + limestone + mineral fertilizer + cattle manure. 
Seeds for seedling production were collected in 16 plants of Hymenaea stigonocarpa in the rural area of Aquidauana - MS, and seeds from $3.5 \mathrm{~g}$ and $4.5 \mathrm{~g}$ were selected for sowing, aiming at emergency homogenization. Seeds were submitted to the process of dormancy breaking with water immersion for 24 hours (MOREIRA et al., 2005) and scarification with sandpaper No. 120. The seeds were sown at $5 \mathrm{~cm}$ depth, irrigated daily at 9 am and $4 \mathrm{pm}$, without control of irrigation management. In each bag, only one seed was sown. Seedling emergence was counted daily after sowing. The polynomial regression analysis was performed for time and substrate factors. The statistical program used was SAS.

After emergence, plant height and stem diameter were evaluated every fortnight. Seven biweekly evaluations of height and diameter were performed at 18, 33, 48, 63, 78, 93 and 108 days after emergence (DAE). At $108 \mathrm{DAE}$, the root system length, plant height, fresh and dry mass of the root and shoot system and total dry mass. The fresh mass was taken to the oven with forced air circulation, at a temperature of $65^{\circ} \mathrm{C}$ until reaching constant mass, for determining the shoot and root dry mass and total dry mass.

Table 2. Chemical analysis of the substrates for production of seedlings of Hymenaea stigonocarpa Mart. Selvíria - MS, $2011-2012$.

\begin{tabular}{|c|c|c|}
\hline & \multicolumn{2}{|l|}{ Limestone } \\
\hline Parameter & Unit (1) & Results \\
\hline Limestone (oxide) & $\%$ de $\mathrm{CaO}(\mathrm{m} / \mathrm{m})$ & 29.5 \\
\hline Magnesium (oxide) & $\%$ de $\mathrm{MgO}(\mathrm{m} / \mathrm{m})$ & 20.4 \\
\hline NP & Eq. $\mathrm{CaCO}_{3}$ & 100.5 \\
\hline \multirow[t]{2}{*}{ RPTN } & $\%(\mathrm{~m} / \mathrm{m})$ & 84.1 \\
\hline & \multicolumn{2}{|l|}{ Manure } \\
\hline Parameter & Unit (1) & Results \\
\hline pH (water 1:10) & --- & 7.0 \\
\hline Humidity $60-650 c$ & $\%(\mathrm{~m} / \mathrm{m})$ & 35.5 \\
\hline Organic carbon & $\mathrm{g} \mathrm{C} / \mathrm{kg}$ & 216 \\
\hline Nitrogen kjeldahl & $\mathrm{g} \mathrm{N} / \mathrm{kg}$ & 1.2 \\
\hline Boron & $\mathrm{mg} \mathrm{B} / \mathrm{kg}$ & $<1.0^{2}$ \\
\hline Calcium & $\mathrm{g} \mathrm{Ca} / \mathrm{kg}$ & 2.1 \\
\hline Copper & $\mathrm{mg} \mathrm{Cu} / \mathrm{Kg}$ & 83.5 \\
\hline Sulfur & $\mathrm{g} \mathrm{S} / \mathrm{kg}$ & 3.4 \\
\hline Iron & $\mathrm{g} \mathrm{Fe} / \mathrm{kg}$ & 21.0 \\
\hline Phosphorus & $\mathrm{g} \mathrm{P} / \mathrm{kg}$ & 7.8 \\
\hline Magnesium & $\mathrm{g} \mathrm{Mg} / \mathrm{kg}$ & 3.9 \\
\hline Manganese & $\mathrm{mg} \mathrm{Mn} / \mathrm{kg}$ & 239 \\
\hline Zinc & $\mathrm{mg} \mathrm{Zn} / \mathrm{kg}$ & 406 \\
\hline
\end{tabular}

(1) Results expressed on a dry basis. (2) Not quantified, less than the limit of quantification. INSTITUTO AGRONÔMICO. Campinas, SP. Center of P\&D of Soils and Enviromental resources- Laboratory of Fertilizers and Residues. TEST METHOD - Determinations performed according to procedure described by MINISTÉRIOS DA AGRICULTURA, PECUÁRIA E ABASTECIMENTO (MAPA), Normative Instruction No. 28. Manual de métodos analíticos oficiais para fertilizantes minerais, orgânicos, organominerais e corretivos. Brasília, June 2007.

The following variables were evaluated: Seedling emergence percentage: daily count up to emergency stabilization at substrate; Height of plants $(\mathrm{PH})$ : was measured using a millimeter ruler, from the lap to the apical bud; Lap diameter (LD): it was measured in the lap region with the aid of a digital caliper. At 108 days after sowing (Figure 3) were evaluated: Length of the root system (CR): the length of the roots from the lap to root cap was measured using a millimeter ruler; Root (RFM) and shoot fresh mass(SFM); Root (RDM) and shoot (leaves) dry matter (SDM)
Seedlings plant material was taken to the oven with forced air circulation, at a temperature of $65^{\circ} \mathrm{C}$ until reaching a constant mass for determining shoot and root dry mass. For obtaining the total dry mass (TDM), the SDM and RDM were added to obtain the total dry matter biomass. Seedlings quality and vigor relations were determined: Shoot/ Lap Diameter (S/D); Relation between shoot and root dry mass (SDM/RDM); Relation between shoot and root fresh mass (SFM/RFM); Relation between length of shoot/root (LS/LR) and Dickson's Quality Score (DQS) (DICKSON et al., 1960): 


$$
D Q S=\frac{T D M(g)}{\frac{P H(\mathrm{~cm})}{L D(\mathrm{~mm})}+\frac{S D M(\mathrm{~g})}{R D M(\mathrm{~g})}}
$$

Experimental design was completely randomized in the factorial scheme with 7 epochs $\mathrm{x}$ 8 substrates. An analysis of variance was performed with deployment of significant interactions with Tukey test for comparisons of substrate factor means and polynomial regression for time factor. Statistical program used for data analysis was SAS.

\section{RESULTS AND DISCUSSION}

Seed emergence of Jatoba in the substrate S1 $(100 \%$ soil) was $100 \%$ and in the substrate S5 (soil + limestone) was 90\% (Figure 1). Both the substrate S1 and S5 had low nutrition and organic matter (Tables 1 and 2) and favored the seedling emergence, being in agreement with the results obtained by Santos et al. (2011) and Costa et al. (2011), who studying the production of Jatoba seedlings observed a greater seed emergence on substrates with lower amount of organic matter, micronutrients and $\mathrm{pH}$.

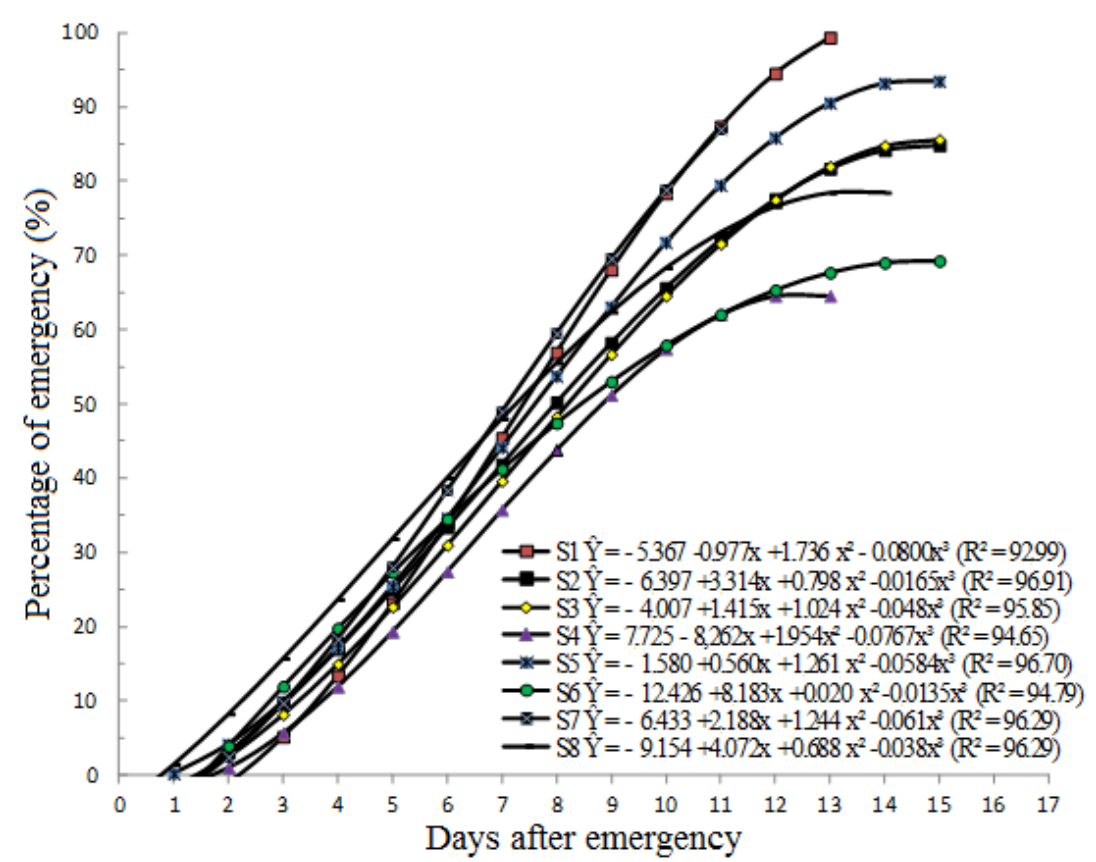

Figure 5: Percentage of emergence of Jatoba in different substrates. Selvíria, MS- 2011. Substrates: S1: soil; S2: soil + cattle manure $(50 \%+50 \%) ;$ S3: soil + mineral fertilizer; S4: soil + mineral fertilizer + cattle manure; S5: soil + limestone; S6: soil + limestone + cattle manure; S7: soil + limestone + mineral fertilizer; S8: soil + limestone + mineral fertilizer + cattle manure.

Many factors may have influenced the high emergence on the substrate S1 (100\% soil), compared to the other substrates tested (Table 1), amongst them are the species adaptation to the type of soil, the physical and chemical characteristics of the soil, $\mathrm{pH}$ and lower amount of organic matter in this substrate. These results corroborate those found by Santos et al. (2011) and Duboc et al. (2006).

It is important to reiterate that some growth characteristics of seedlings such as height and dry mass are also relevant factors when choosing the best substrate used for seedling production. To choose the best substrate, the producer must also be aware of the production costs and seedling growth. In general, a lower root adaptation to soils with loamy-clayey characteristics (substrates S2, S4, S6 and S8) and a better adaptation to clayey soils was observed (substrates S1, S3, S5 and S7).

According to the height data in different substrates, the seedlings development was different depending on the substrate where the seedlings were accommodated. At $18 \mathrm{DAE}$, the height development was uniform and did not differ statistically. At 33 and 48 DAE, the substrates S1, S2, S3, S5 and S7 showed the highest heights, which did not differ from each other at 5\%, however, from 63 DAE the plants that were on the substrates with the addition of organic matter did not follow the development of the other seedlings. Seedlings that developed on the 
substrates S2, S4, S6 and S8 obtained the lowest heights.

At, 108 DAE, the highest height occurred on the S1 substrate (soil), where the average height reached $33.13 \mathrm{~cm}$, however, there was no difference in the seedlings on the substrates S3, S5 and S7. In their studies, Santos et al. (2012) observed that the soil substrate $(100 \%$ soil) was a suitable substrate for the Jatoba seedlings and the greater the addition of organic compounds to the substrate composition, the lower the seedlings development.
Through these data, we observed that the mineral increment or limestone up to 108 DAE did not result in an increase in their height under the environmental conditions tested (Table 3). The Jatoba seedlings obtained a better development on substrates with lower macro and micronutrient contents, perhaps due to the adaptation of the species to more acidic soils (Table 1) (Costa et al., 2011). It is important to note that the lowest base saturation (BS) and cation exchange capacity (CEC) were found in this substrate.

Table 3. Plant height $(\mathrm{cm})$ of Jatoba seedlings on substrates $(\mathrm{S})$ at different days after emergence grown in Selvíria-MS.

\begin{tabular}{llllllll}
\hline \multicolumn{7}{l}{ Days after emergence - DAE } \\
\cline { 2 - 8 } Substrates & 18 & 33 & 48 & 63 & 78 & 93 & 108 \\
\hline S1 & $12.83 \mathrm{a}$ & $18.84 \mathrm{a}$ & $22.84 \mathrm{a}$ & $26.65 \mathrm{a}$ & $28.34 \mathrm{a}$ & $32.52 \mathrm{a}$ & $33.13 \mathrm{a}$ \\
S2 & $12.56 \mathrm{a}$ & $16.51 \mathrm{a}$ & $21.66 \mathrm{a}$ & $23.54 \mathrm{~b}$ & $24.33 \mathrm{~b}$ & $24.57 \mathrm{~b}$ & $25.06 \mathrm{~b}$ \\
S3 & $11.93 \mathrm{a}$ & $17.31 \mathrm{a}$ & $21.25 \mathrm{a}$ & $26.91 \mathrm{a}$ & $28.82 \mathrm{a}$ & $31.28 \mathrm{a}$ & $32.60 \mathrm{a}$ \\
S4 & $12.83 \mathrm{a}$ & $15.79 \mathrm{~b}$ & $19.79 \mathrm{~b}$ & $22.91 \mathrm{~b}$ & $22.25 \mathrm{~b}$ & $22.54 \mathrm{~b}$ & $22.00 \mathrm{~b}$ \\
S5 & $12.31 \mathrm{a}$ & $17.08 \mathrm{a}$ & $21.02 \mathrm{a}$ & $25.77 \mathrm{~b}$ & $27.36 \mathrm{a}$ & $29.69 \mathrm{a}$ & $30.22 \mathrm{a}$ \\
S6 & $11.62 \mathrm{a}$ & $14.96 \mathrm{~b}$ & $19.00 \mathrm{~b}$ & $22.88 \mathrm{~b}$ & $23.62 \mathrm{~b}$ & $21.70 \mathrm{~b}$ & $22.51 \mathrm{~b}$ \\
S7 & $12.91 \mathrm{a}$ & $18.00 \mathrm{a}$ & $21.56 \mathrm{a}$ & $26.67 \mathrm{a}$ & 29.00 & $30.51 \mathrm{a}$ & $33.02 \mathrm{a}$ \\
S8 & $12.07 \mathrm{a}$ & $14.89 \mathrm{~b}$ & $19.42 \mathrm{~b}$ & $21.89 \mathrm{~b}$ & $21.89 \mathrm{~b}$ & $20.00 \mathrm{~b}$ & $20.46 \mathrm{~b}$ \\
\hline
\end{tabular}

Same letter in the columns do not differ at 5\% probability by Tukey test. Substrates: S1: soil; S2: soil + cattle manure $(50 \%+50 \%)$; S3: soil + mineral fertilizer; S4: soil + mineral fertilizer + cattle manure; S5: soil + limestone; S6: soil + limestone + cattle manure; S7: soil + limestone + mineral fertilizer; S8: soil + limestone + mineral fertilizer + cattle manure.

What may often cause less development in Jatoba seedlings on organic substrates, among many other factors, is the high micronutrients content (SANTOS et al., 2011). In the trial, we observed that the substrates with high levels of manure as in the substrates S2, S4, S6 and S8, high content of Na and micronutrients such as $\mathrm{Zn}$ and $\mathrm{Cu}$ (Table 1) were found, followed by a lower development in height.

High content of $\mathrm{Cu}, \mathrm{Mn}$ and $\mathrm{Zn}$, which are very high values when compared to other nutrients, was observed in the chemical analysis of pure manure (Table 2). This may have caused a negative effect on the Jatoba seedlings, impairing the uptake of other nutrients and reflecting on their development. Duboc et al. (1996), when analyzing nutritional data of Jatoba seedlings, verified that large contents of $\mathrm{Zn}$ can cause the inhibition of some nutrients and damage the seedling growth.

Mineral fertilizers and limestone benefited the growth of the plants, however, the average height of the Jatoba seedlings on soil (S1) was higher than the average of the fertilized substrates. Substrates containing manure in its composition (substrates S2, S4, S6 and S8) showed seedlings with the smallest development and the best substrates for the growth of Jatoba seedlings were the substrates S1, S3, S5 and S7.

Costa et al. (2011) and Santos et al. (2011) highlighted that the substrates with large amounts of organic matter were not beneficial to the Jatoba seedlings development thus corroborating the data from this trial, in which the lowest seedling development occurred in substrates with high proportions of manure and high concentrations of organic matter (Table 1).

The lowest diameter of the seedlings at 108 DAE occurred on substrate S6 with a mean of 4.20 $\mathrm{cm}$, differing from the other substrates (Table 4). The same occurred with the diameter on substrates S2 and S8. The addition of manure did not benefit the diameter growth of the seedlings developed in these substrates.

The greatest shoot fresh masses of the Jatoba seedlings occurred on the substrates S1, S2 and S7 with $10.72 \mathrm{~g}, 8.43 \mathrm{~g}$ and $9.55 \mathrm{~g}$, respectively (Table 5). However, for the shoot dry mass, the substrate S7 (soil + limestone + mineral fertilizer) stood out from the other substrates with $3.77 \mathrm{~g}$, but it not differed from substrates S1, S2, S3, S5 and S7. 
Table 4. Diameter $(\mathrm{cm})$ of Jatoba seedlings on substrates $(\mathrm{S})$ at different days after emergence grown in Selvíria-MS.

\begin{tabular}{llllllll}
\hline \multirow{2}{*}{ Substrates } & \multicolumn{6}{l}{ Days after emergence } & \multicolumn{7}{l}{} \\
\cline { 2 - 7 } & 18 & 33 & 48 & 63 & 78 & 93 & 108 \\
\hline S1 & $3.67 \mathrm{a}$ & $3.13 \mathrm{a}$ & $3.48 \mathrm{a}$ & $3.63 \mathrm{~b}$ & $4.40 \mathrm{a}$ & $4.41 \mathrm{a}$ & $4.55 \mathrm{a}$ \\
S2 & $3.65 \mathrm{a}$ & $3.10 \mathrm{a}$ & $3.68 \mathrm{a}$ & $3.66 \mathrm{~b}$ & $4.29 \mathrm{a}$ & $4.50 \mathrm{a}$ & $4.49 \mathrm{a}$ \\
S3 & $3.58 \mathrm{a}$ & $3.14 \mathrm{a}$ & $3.91 \mathrm{a}$ & $3.75 \mathrm{~b}$ & $4.34 \mathrm{a}$ & $4.49 \mathrm{a}$ & $4.77 \mathrm{a}$ \\
S4 & $3.53 \mathrm{a}$ & $3.03 \mathrm{a}$ & $3.73 \mathrm{a}$ & $3.62 \mathrm{~b}$ & $4.35 \mathrm{a}$ & $4.48 \mathrm{a}$ & $4.68 \mathrm{a}$ \\
S5 & $3.48 \mathrm{a}$ & $3.03 \mathrm{a}$ & $2.94 \mathrm{~b}$ & $3.72 \mathrm{~b}$ & $4.34 \mathrm{a}$ & $4.59 \mathrm{a}$ & $4.69 \mathrm{a}$ \\
S6 & $3.50 \mathrm{a}$ & $3.29 \mathrm{a}$ & $3.18 \mathrm{~b}$ & $3.44 \mathrm{~b}$ & $3.98 \mathrm{~b}$ & $4.29 \mathrm{a}$ & $4.20 \mathrm{~b}$ \\
S7 & $3.56 \mathrm{a}$ & $3.18 \mathrm{a}$ & $3.13 \mathrm{~b}$ & $3.60 \mathrm{~b}$ & $3.99 \mathrm{~b}$ & $4.48 \mathrm{a}$ & $4.51 \mathrm{a}$ \\
S8 & $3.55 \mathrm{a}$ & $3.16 \mathrm{a}$ & $3.24 \mathrm{~b}$ & $3.85 \mathrm{a}$ & $4.11 \mathrm{a}$ & $4.20 \mathrm{a}$ & $4.48 \mathrm{a}$ \\
\hline
\end{tabular}

Same letter in the columns do not differ at $5 \%$ probability by Tukey test. Substrates: S1: soil; S2: soil + cattle manure $(50 \%+50 \%) ;$ S3: soil + mineral fertilizer; S4: soil + mineral fertilizer + cattle manure; S5: soil + limestone; S6: soil + limestone + cattle manure; S7: soil + limestone + mineral fertilizer; S8: soil + limestone + mineral fertilizer + cattle manure.

Table 5. Means test of shoot and root fresh and dry masses and length of root in Jatoba seedlings on different substrates (S) at 120 days after emergence. Selvíria - MS, 2011/2012.

\begin{tabular}{llllll}
\hline Substrates & SFM & SDM & RFM & RDM & LR \\
\hline S1 & $10.72 \mathrm{a}$ & $4.34 \mathrm{a}$ & $12.30 \mathrm{a}$ & $5.60 \mathrm{a}$ & $34.20 \mathrm{a}$ \\
S2 & $8.43 \mathrm{ab}$ & $3.14 \mathrm{ab}$ & $9.87 \mathrm{abc}$ & $3.78 \mathrm{bcd}$ & $29.10 \mathrm{ab}$ \\
S3 & $11.15 \mathrm{a}$ & $4.33 \mathrm{a}$ & $11.98 \mathrm{a}$ & $5.33 \mathrm{ab}$ & $30.06 \mathrm{a}$ \\
S4 & $6.43 \mathrm{bc}$ & $2.43 \mathrm{bc}$ & $9.50 \mathrm{abc}$ & $3.68 \mathrm{~cd}$ & $30.50 \mathrm{a}$ \\
S5 & $10.63 \mathrm{bc}$ & $4.27 \mathrm{a}$ & $11.51 \mathrm{ab}$ & $4.97 \mathrm{abc}$ & $28.00 \mathrm{a}$ \\
S6 & $5.67 \mathrm{bc}$ & $1.98 \mathrm{bc}$ & $7.94 \mathrm{abc}$ & $3.06 \mathrm{~d}$ & $28.10 \mathrm{ab}$ \\
S7 & $9.55 \mathrm{a}$ & $3.77 \mathrm{a}$ & $8.92 \mathrm{abc}$ & $4.09 \mathrm{abcd}$ & $28.90 \mathrm{ab}$ \\
S8 & $5.53 \mathrm{c}$ & $1.91 \mathrm{c}$ & $7.97 \mathrm{abc}$ & $3.77 \mathrm{~d}$ & $23.30 \mathrm{~b}$ \\
\hline
\end{tabular}

Same letter in the columns do not differ at 5\% probability by Tukey test. Substrates: S1: soil; S2: soil + cattle manure $(50 \%+50 \%) ;$ S3: soil + mineral fertilizer; S4: soil + mineral fertilizer + cattle manure; S5: soil + limestone; S6: soil + limestone + cattle manure; S7: soil + limestone + mineral fertilizer; S8: soil + limestone + mineral fertilizer + cattle manure. SFM = shoot fresh mass; SDM = shoot dry mass; RFM = root fresh mass; RDM = root dry mass; $L R=$ length of root.

The lowest dry mass occurred on substrate S8 (soil + limestone + mineral fertilizer + organic compost) with $1.91 \mathrm{~g}$, which not differed from substrates S4 and S6 with $2.43 \mathrm{~g}$ and $1.98 \mathrm{~g}$. Larger root fresh masses occurred on S1, S2, S3 with 12.30 g, $9.87 \mathrm{~g}$ and $11.98 \mathrm{~g}$, respectively. However, they not differed from the other substrates, and the lowest fresh mass was found in substrate S6 (7.94 g) and S8 (7.97 g). The substrate S1 (soil) stood out with root dry mass of $5.60 \mathrm{~g}$, not differing from substrates S3, S5 and S7. It was also possible to observe low accumulation of root dry mass in seedlings that have developed on substrates S2, S4, S6 and S8.

In the $100 \%$ soil substrate (S1), where the lowest levels of phosphorus $\left(4 \mathrm{mg} / \mathrm{dm}^{3}\right)$, potassium and $\mathrm{pH}$ were found, the addition of these nutrients and the $\mathrm{pH}$ may have interfered in the growth of the seedlings root. Duboc et al. (1996) observed that the low $\mathrm{K}$ requirement in Jatoba seedlings and high levels of this nutrient may influence the othernutrients' uptake, especially, Ca.

The length of roots did not differ between the different substrates used, however, it is very important to highlight the growth of roots on S1 (34 $\mathrm{cm})$ and the lowest length of root on substrate S8 $(23.30 \mathrm{~cm})$ (Table 6). Possibly, the growth of the roots that developed on substrate S8 did not have their development stimulated due to the chemical characteristics found in this substrate. Root size resulted in a lower shoot and root system relation.

The highest means of TDM and S/D were found for the substrates S1, S3, S5 and S7, which not differed among them. The highest means for SFM/RFM, SDM/RDM and LS/LR occurred in S7 (soil + limestone + mineral fertilizer), however, it not differed from S1 (soil). The highest mean of DQS occurred in S3 (soil + mineral fertilizer) and S5 (soil + limestone), but not differed from S1 (soil), and the lowest DQS occurred in S6 (soil + limestone + cattle manure). Through the variables of the Jatoba seedlings is possible to define a nonadaptation of the seedlings on substrates with high proportion of organic matter. High levels of organic matter can be used in a nutritional imbalance, resulting in lower quality seedlings. 
Table 6. Means test in Jatoba seedlings at different substrates (S) at 108 days after emergence. Selvíria - MS, 2011/2012.

\begin{tabular}{lllllll}
\hline Substrates & TDM $(\mathrm{g})$ & S/D & SFM/RFM & SDM/RDM & LS/LR & DQS \\
\hline S1 & $9.93 \mathrm{a}$ & $7.31 \mathrm{a}$ & $0.91 \mathrm{ab}$ & $0.78 \mathrm{abc}$ & $0.994 \mathrm{abc}$ & $1.23 \mathrm{a}$ \\
S2 & $6.92 \mathrm{bcd}$ & $5.66 \mathrm{bc}$ & $0.86 \mathrm{ab}$ & $0.86 \mathrm{ab}$ & $0.86 \mathrm{bcd}$ & $1.16 \mathrm{ab}$ \\
S3 & $9.66 \mathrm{a}$ & $6.83 \mathrm{a}$ & $0.95 \mathrm{ab}$ & $0.85 \mathrm{abc}$ & $1.08 \mathrm{ab}$ & $1.26 \mathrm{a}$ \\
S4 & $6.11 \mathrm{~cd}$ & $4.78 \mathrm{~cd}$ & $0.68 \mathrm{ab}$ & $0.65 \mathrm{bc}$ & $0.64 \mathrm{~d}$ & $1.13 \mathrm{ab}$ \\
S5 & $9.24 \mathrm{ab}$ & $6.51 \mathrm{ab}$ & $0.96 \mathrm{ab}$ & $0.89 \mathrm{ab}$ & $1.09 \mathrm{a}$ & $1.26 \mathrm{a}$ \\
S6 & $5.04 \mathrm{~d}$ & $5.42 \mathrm{~cd}$ & $0.79 \mathrm{~b}$ & $0.65 \mathrm{bc}$ & $0.83 \mathrm{dc}$ & $0.83 \mathrm{~b}$ \\
S7 & $7.87 \mathrm{abc}$ & $7.42 \mathrm{a}$ & $1.12 \mathrm{a}$ & $0.95 \mathrm{a}$ & $1.15 \mathrm{a}$ & $0.95 \mathrm{ab}$ \\
S8 & $5.28 \mathrm{~d}$ & $4.61 \mathrm{~d}$ & $0.72 \mathrm{ab}$ & $0.58 \mathrm{c}$ & $0.95 \mathrm{abc}$ & $1.02 \mathrm{ab}$ \\
\hline
\end{tabular}

Same letter in the columns do not differ at 5\% probability by Tukey test. Substrates: S1: soil; S2: soil + cattle manure $(50 \%+50 \%) ;$ S3: soil + mineral fertilizer; S4: soil + mineral fertilizer + cattle manure; S5: soil + limestone; S6: soil + limestone + cattle manure; S7: soil + limestone + mineral fertilizer; S8: soil + limestone + mineral fertilizer + cattle manure. TDM = total dry mass; S/D = Relation shoot/lap diameter; SFM/RFM = Relation shoot/root fresh mass; SDM/RDM: Relation shoot/root dry mass; LS/LR = Relation between length of shoot/root; DQS: Dickson's Quality Score.

In general, the choice of the substrate for producing native fruit trees requires several research, since it is necessary to evaluate many factors, from the physical-chemical characteristics to the material costs to be added in the substrate composition, and if the native fruit species will have an adaptation at field. The results indicate a great potential in the development of Jatoba in soils considered unsuitable for most commercial crops. However, other research should be done with the plants in the field to investigate the adaptability $\mathrm{x}$ costs $\mathrm{x}$ environment $\mathrm{x}$ less dependence of the producer on the external inputs.

\section{CONCLUSIONS}

The substrate S1 (soil) provided higher shoot and root biomass accumulation under the experimental conditions tested.

The addition of the manure compound not benefited the development of Jatoba seedlings.

RESUMO: O jatobazeiro é uma espécie frutífera de grande importância para fauna brasileira, culinária e recuperação de áreas degradadas. Este trabalho teve por objetivo a formação de mudas de jatobazeiro em diferentes substratos. Foi realizado na área experimental da Fazenda de Ensino, Pesquisa e Extensão da Unesp, Campus de Ilha Solteira, SP, localizada em Selvíria/MS, no período de 13 de Outubro de 2011 a 11 de fevereiro de 2012. Para a produção das mudas utilizou-se viveiro telado polipropileno preto (Sombrite ${ }^{\circledR}$ ) $\mathrm{com} 50 \%$ de redução de luz e sacos plásticos preto de 15 x 21,5 cm (1,8 L) preenchidos com diferentes substratos: (S1) solo (testemunha); (S2) solo (50\% + esterco bovino (50\%); (S3) solo+ adubo mineral; (S4) solo (50\%) + adubo mineral + esterco (50\%); (S5) solo + calcário; (S6) solo (50\%) + calcário + esterco (50\%); (S7) solo + calcário + adubo mineral e (S8) solo $(50 \%)$ + calcário + adubo mineral + esterco $(50 \%)$. Foram avaliadas diariamente a emergência das sementes e quinzenalmente após a emergência das sementes foram verificadas a altura e diâmetro de caule. Aos 120 dias após a semeadura foi verificado o comprimento do sistema radicular (CR), fitomassas das matérias secas do sistema radicular e da parte aérea, massa seca total (MST), relação parte aérea/diâmetro do colo (RPAD), relação massa fresca da parte aérea/massa fresca do sistema radicular (RMF), relação massa seca da parte aérea/massa seca do sistema radicular (RMS), relação comprimento da parte aérea/comprimento do sistema radicular RPA/SR e Índice de Qualidade de Dickson (IQD). O delineamento experimental utilizado foi inteiramente casualizado no esquema fatorial com 7 avaliações x 8 substratos. Procedeu-se análise de variância dcom desdobramento de interações significativas com teste de Tukey para comparações das médias do fator substrato e regressão polinomial pata fator tempo. O tratamento substrato solo puro (S1) proporcionou as mudas de jatobazeiro maior acúmulo de fitomassa da matéria seca aérea e radicular. A adição do esterco aos substratos não beneficiou o desenvolvimento das mudas do jatobazeiro.

PALAVRAS-CHAVE: Adubo mineral. Solo. Esterco. Jatobazeiro. Propagação.

\section{REFERENCES}

COSTA, E.; LEAL, P. A. M.; REGO, N. H.; BENATTI, J. Desenvolvimento inicial de mudas de jatobazeiro do cerrado em Aquidauana -MS. Revista Brasileira de Futicultura, Jaboticabal, v. 33, p. 215-226, 2011. 
DICKSON, A.; LEAF, A. L.; HOSNER, J. F. Quality appraisal of white spruce and white pine seeding stock in nurseries. Forestry Chronicle, Ottawa, v. 36, p. 10-13, 1960. https://doi.org/10.5558/tfc36010-1

DUBOC, E.; VENTURIM, N.; VALE, F. R.; DAVIDE, A. C. Nutrição do jatobá (Hymenaea courbaril L. var. stilbocarpa (Hayne) Lee et Lang). Cerne, Lavras, v.2, n.1, 1996. 12 p.

EMBRAPA. Sistema Brasileiro e Classificação do solo. Rio de Janeiro: CNPSO, 1999. 412 p.

FARIA, J. P.; SANO, S. M.; AGOSTINI-COSTA, T. S. Jatobá-do-Cerrado. In: Frutas nativas da região Centro-Oeste do Brasil. Brasília: EMBRAPA Recursos Genéticos e Biotecnologia, 2006. Cap. 11. P.173-186.

HERNANDEZ, F. B. T.; LEMOS FILHO, M. A. F.; BUZETTI, S. Software HIDRISA e o balanço hídrico de Ilha Solteira. Ilha Solteira. Faculdade de Engenharia de Ilha Solteira - UNESP Área de Hidráulica e Irrigação, 1995. 45p.

LORENZI, H. Arvóres brasileiras: manual de identificação e cultivo de plantas arbóreas nativas do Brasil. 3. ed. Nova Odessa-SP: Instituto Plantarum, 2000. 352 p.

MOREIRA, M. A. T.; PAIVA SOBRINHO, S.; SILVA, S. J.; SIQUEIRA, A. G. Superação da dormência em sementes de jatobá Hymenaea courbaril L. In: Seminário de Iniciação Científica, 3., Jornada de Pesquisa e PósGraduação da Universidade Estadual de Goias -UEG, 1., 2005, Anapolis. Anais... GOIÂNIA:UEG, 2005.

NICODEMOS, M. L. F.; LAURA, V. A.; MELOTTO, A. M.; BOCCHESE, R. A.; SCHUNKE.; R. M.; BARBOSA, R. A. Avaliação inicial de espaçamentos para o plantio de espécies arbóreas nativas para o fomento de sistemas no Mato Grosso do Sul. REUNIÃO ANUAL DA SOCIEDADE BRASILEIRA DE ZOOTECNIA, 44., 2007, Jaboticabal-SP. Resumos... Jaboticabal-SP: Universidade Estadual Paulista, 2007.

SÃO JOSÉ, A. R.; SOUZA, I. V. B. Propagação da mangueira. P.33-39 In: Manga: produção e comercialização. Vitória da Conquista, UESB, 1992. 39p.

SANO, S. M.; FONSECA, C. E. L. Estabelecimento de progênies de jatobá (Hymenaea spp) em plantios puros no Cerrado. Planaltina-DF: Embrapa Cerrados, 2003. 14p. (Boletim de Pesquisa e Desenvolvimento número 110).

SANTOS, L. C. R.; COSTA, E.; LEAL, P. A. M.; NARDELLI, E. M. V.; SOUZA, G. S. A. Ambientes protegidos e substratos com concentrações de esterco comercial e solo na formaçã de mudas de jatobazeiro em Aquidauana - MS. Engenharia Agrícola, Jaboticabal, v. 31, n. 2, p. 249-259, 2011.

SCREMIN-DIAS, E. et al (Org.). Produção de sementes de espécies florestais nativas. Campo Grande- MS: Universidade Federal do Mato Grosso do Sul, UFMS, 2006. 43 p. (Série Rede de sementes do Pantanal).

SILVA, D. B.; SILVA, J. A.; JUNQUEIRA, N. T. V.; ANDRADE, L. R. M. Frutas do Cerrado. Embrapa Informações tecnológicas. Brasília. DF, 2001. 179p. 